Division of Geological \& Geophysical Surveys

RAW-DATA FILE 2016-3

\title{
MAJOR-OXIDE AND TRACE-ELEMENT GEOCHEMICAL DATA FROM ROCKS COLLECTED IN 2015 IN LOWER COOK INLET, INISKIN-TUXEDNI REGION, ALASKA
}

by

Alicja Wypych, Robert J. Gillis, Paul M. Betka, Paul L. Decker

$\$ 2.00$

2016

THIS REPORT HAS NOT BEEN REVIEWED FOR

TECHNICAL CONTENT OR FOR CONFORMITY TO THE

EDITORIAL STANDARDS OF DGGS

\author{
Released by \\ STATE OF ALASKA \\ DEPARTMENT OF NATURAL RESOURCES \\ Division of Geological \& Geophysical Surveys \\ 3354 College Road
}

Fairbanks, Alaska 99709-3707 


\title{
MAJOR-OXIDE AND TRACE-ELEMENT GEOCHEMICAL DATA FROM ROCKS COLLECTED IN 2015 IN LOWER COOK INLET, INISKIN-TUXEDNI REGION, ALASKA
}

\author{
by \\ Alicja Wypych ${ }^{1}$, Robert J. Gilliss ${ }^{1}$, Paul M. Betka ${ }^{2}$, and Paul L. Decker ${ }^{3}$
}

\section{INTRODUCTION}

Lower Cook Inlet, Alaska, has been of interest since the mid-19th century for its petroleum potential (Martin, 1905). The Iniskin-Tuxedni Bay area contains excellent exposures of nearly all of the Mesozoic succession, including most of the stratigraphic sections that define the interval and the petroleum source rocks that comprise the basin (Magoon and Anders, 1992). However, an underdeveloped understanding of the Mesozoic petroleum system has led the Alaska Department of Natural Resources’ Division of Geological \& Geophysical Surveys and Division of Oil and Gas, and the U.S. Geological Survey to collaborate on a multi-year project that includes two major mapping campaigns funded in part by federal STATEMAP grants in 2013 and 2015 (Gillis, 2014, 2015; Herriott, 2016). Geologic mapping between Chinitna Bay and the Johnson River during the 2015 field season encompassed volcanic arc rocks northwest of the Bruin Bay fault system, and Mesozoic forearc basin stratigraphy extending to the Cook Inlet coast. To understand and represent the complexity of the volcanic arc systems in the region, we analyzed ten samples of volcanic rocks, two samples of gabbro sill, and one mafic dike sample for major and minor oxides and trace elements. Although mineralization was not noted in the samples collected for major oxide analysis, findings of interest include: one sample with weak $\mathrm{Cr}$ and Ni enrichment, three samples with lightly elevated As, and slight $\mathrm{S}$ anomalies (0.37 wt\% and $0.25 \mathrm{wt} \%$ ) in samples described as Talkeetna Formation. The Talkeetna Formation sample with $0.37 \mathrm{wt} \% \mathrm{~S}$ also had elevated $\mathrm{Cu}(321 \mathrm{ppm})$ and As (58 ppm).

The analytical data tables associated with this report are available in digital format as comma-separated values (CSV) file. Additional details about the organization of information are noted the accompanying metadata file. All files can be downloaded from the DGGS website (doi:10.14509/29575).

\section{DOCUMENTATION OF METHODS}

\section{SAMPLE COLLECTION}

Igneous rock samples showing little alteration or weathering were collected for whole-rock major-oxide, minoroxide, and trace-element analyses to aid in classification and study of petrogenesis and tectonic setting. Most samples are 'grab' samples, which were collected for their overall representation of the outcrop. Location data were collected with handheld GPS devices with location accuracy errors typically less than $10 \mathrm{~m}$; latitude and longitude were recorded and reported using the NAD27 datum.

\section{SAMPLE PREPARATION}

Rock samples were processed by ALS Minerals using their PREP-31 package. The samples were crushed to better than 70 percent passing $2 \mathrm{~mm}$, and a 250 g split was pulverized to better than 85 percent passing 75 microns. Prior to crushing, samples for whole-rock analysis were trimmed by DGGS staff to remove weathering, and cut surfaces were sanded to remove any saw metal.

\footnotetext{
${ }^{1}$ Alaska Division of Geological \& Geophysical Surveys, 3354 College Rd., Fairbanks, AK 99709-3707; alicja.wypych@alaska.gov

${ }^{2}$ Alaska Division of Geological \& Geophysical Surveys, 3354 College Rd., Fairbanks, AK 99709-3707; now at Lamont-Doherty Earth Observatory, Columbia University, 61 Route 9W, Palisades, NY 10964

${ }^{3}$ Alaska Division of Oil and Gas, 550 W. 7th Ave., Suite 1100, Anchorage, AK 99501-3560
} 


\section{ANALYTICAL METHODS}

Samples were analyzed for a variety of suites of major and trace elements depending on the sample type. In addition to ALS Minerals' accredited (ISO/IEC 17025-2005) internal quality-control program, DGGS monitored analysis quality with one standard reference material per batch of 20 analyses.

For whole-rock geochemistry samples, major and minor oxides were analyzed using lithium metaborate fusion digestion and ICP-AES (ALS Minerals method ME-ICP06). Trace elements, including rare-earth elements, were determined using lithium metaborate fusion digestion and ICP-MS (ALS Minerals method ME-MS81). Ag, Cd, Co, $\mathrm{Cu}, \mathrm{Li}, \mathrm{Mo}, \mathrm{Ni}, \mathrm{Pb}, \mathrm{Sc}$, and $\mathrm{Zn}$ were determined using four-acid digestion and ICP-AES (ALS Minerals method ME-4ACD81); and As, Bi, Hg, In, Re, Sb, Se, Te, and Tl were determined by aqua regia digestion followed by ICP-MS (ALS Minerals method ME-MS42). Total C and S were analyzed by Leco furnace (ALS Minerals methods C-IR07 and S-IR08, respectively).

For each sample, data tables contain either assay values or coded-value place holders (null = not analyzed; $-1=$ the element's assay result is less than the lower detection limit for the method; -2 = the element's assay result is greater than the upper detection limit for the method). Detection limits for each of the reported elemental values obtained by the various methods are documented in the metadata file.

\section{ACKNOWLEDGMENTS}

Primary funding for the lower Cook Inlet work is provided by the State of Alaska. Geologic mapping during the 2015 field season was supported by the U.S. Geological Survey's National Cooperative Geologic Mapping Program (NCGMP) through STATEMAP (award number G15AC00199). The mapping crew thanks NCGMP Coordinator Doug Howard for visiting the study area in July 2015. Land access for this work was permitted by Lake Clark National Park \& Preserve, Cook Inlet Region, Inc., and the following Alaska Native village corporations: Chickaloon, Knik, Ninilchik, Salamatof, Seldovia, and Tyonek. Thanks to Buck Mangipane and Jeff Shearer at Lake Clark National Park \& Preserve and Jason Brune and Tanisha Gleason of Cook Inlet Region, Inc. for their assistance in permitting.

\section{REFERENCES}

Gillis, R.J., ed., 2014, Cook Inlet program 2013 field studies-Observations and preliminary interpretations from new 1:63,360-scale geologic mapping of the Iniskin Peninsula, lower Cook Inlet, Alaska: Alaska Division of Geological \& Geophysical Surveys Preliminary Interpretive Report 2014-2, 31 p. doi: $\underline{10.14509 / 27303}$

Gillis, R.J., ed., 2015, Overview of 2014 energy-focused studies in Susitna basin, south-central Alaska, and preliminary results: Alaska Division of Geological \& Geophysical Surveys Preliminary Interpretive Report 2015-3, 34 p. doi: $10.14509 / 29408$

Herriott, T.M., ed., 2016, Petroleum-related geologic studies in lower Cook Inlet during 2015, Iniskin-Tuxedni region, south-central Alaska: Alaska Division of Geological \& Geophysical Surveys Preliminary Interpretive Report 2016-1, 78 p. doi: $10.14509 / 29532$

Magoon, L.B., and Anders, D.E., 1992, Oil-to-source-rock correlation using carbon-isotopic data and biological marker compounds, Cook Inlet-Alaska Peninsula, Alaska, in Moldowan, J.M., Albrecht, Pierre, and Philp, R.P., eds., Biological markers in sediments and petroleum: Englewood Cliffs, N.J., Prentice-Hall, p. 241-274.

Martin, G.C., 1905, The petroleum fields of the Pacific coast of Alaska, with an account of the Bering River coal deposits: U.S. Geological Survey Bulletin 250, 64 p. http://dggs.alaska.gov/pubs/id/3368 